\title{
Determinant Factors of Stunting in Under-Five Children
}

\author{
Yusni Podungge ${ }^{1 *}$ (D) Endah Yulianingsih ${ }^{1}$, Hasnawatty S. Porouw ${ }^{1}$, Elsa Saraswati ${ }^{1}$, Magdalena Martha Tompunuh ${ }^{1}$, Juli Gladis \\ Claudia ${ }^{1}$, Rabia Zakaria ${ }^{1}$, Rahma Labatjo ${ }^{2}$ \\ ${ }^{1}$ Department of Midwifery, Gorontalo Polytechnic of Health, Gorontalo, Indonesia; ${ }^{2}$ Department of Nutrition, Gorontalo \\ Polytechnic of Health, Gorontalo, Indonesia
}

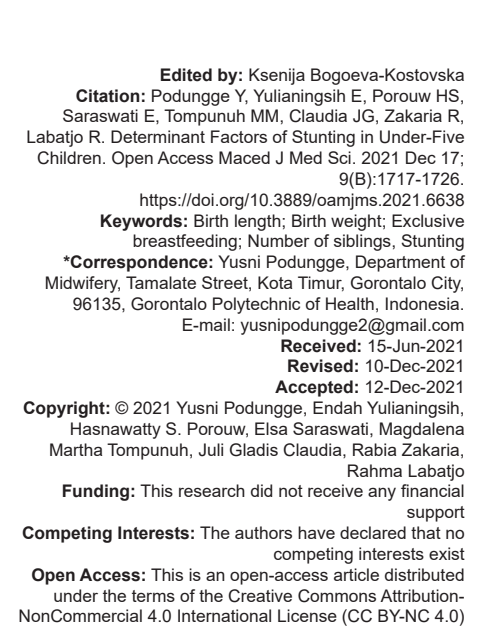

Introduction

The high rate of stunting cases is one of the serious nutritious problems that still persist in Indonesia [1]. The problem is potentially impactful on the quality of the country's human resources. The stunting info-graphic data released by the WHO in 2016 showed that about 162 million children worldwide experienced stunting. The Sub-Saharan Africa and Southern Asia regions are the home of three-quarters of global stunting cases. The data revealed that $40 \%$ of under-five children in Sub-Saharan Africa experienced stunting; in South Asia, the percentage of stunting was at $39 \%$.

In comparison with other countries in Southeast Asia, Indonesia's stunting rate places on top of Vietnam. The results of the South East Asian Nutrition Survey (SEANUTS) in 2010-2011 had ranked Indonesia as the country with the highest stunting rate in the Southeast Asia region, far higher than Malaysia, Thailand, and Vietnam.

Indonesia has since progressed to decrease the poverty rate from $16.6 \%$ to $12.5 \%$ in 2010 .
However, the children's malnutrition problems still persist as one of the most serious concerns. The 2010 Baseline Health Survey or Riskesdas has shown that the prevalence of low birth weight (LBW) in under-five children has decreased to less than 18\%; still, the prevalence of stunting persists at a high rate, and thus maintaining its status as one of the alarming public health concerns. The 2010 data above also indicated that $35.6 \%$ or $7,688,000$ children in Indonesia were categorized as stunting; to worsen, the percentage increased to $37.2 \%$ in the Baseline Health Survey data in 2013. A total of 24 provinces (from 34 provinces in Indonesia) were indicated to have greater than $30 \%$ prevalence of stunting, with variation ranging from $30 \%$ to $58 \%$ [2].

As shown by data in 2017, the percentage of stunting in Gorontalo province was at $31.7 \%$; the rate was relatively better than in 2016 (33\%) or in 2015 (36.5\%). At a regional scope, the prevalence of stunting in the regencies/municipality in the province (Gorontalo Provincial Office of Health) was as follows: Gorontalo municipality sat at the top place with $36.2 \%$ rate, followed by Pohuwato (33.2\%), Boalemo (32.5\%), Gorontalo regency (32.3\%), North Gorontalo regency 
$(27.5 \%)$, and Bone Bolango regency at the bottom $(25.5 \%)$. On top of that, the data from the Gorontalo Municipal Office of Health in 2018 found that 33 children experienced very stunted growth and 106 children with stunted growth; the highest rate was in Kota Tengah district, with 24 stunted children and ten very stunted children.

On this ground, the study regards the significance of conducting research on the determinant factor of stunting cases in 24-59-month-old children in the coverage area of Community Health Center (henceforth, Puskesmas) Kota Tengah, Gorontalo. Further, the present study aims to analyze the determinant factors of stunting cases in 24-59-month-old children in the working area of Puskesmas Kota Tengah, Gorontalo.

\section{Materials and Methods}

\section{Research design}

The study relied on a case-control study.

\section{Research site and duration}

This research was conducted in the coverage area of Puskesmas Kota Tengah, Gorontalo, on 5-26 April 2019.

\section{Research variables}

This present work involved independent variables of birth length, birth weight, provision of exclusive breastfeeding, and the number of siblings. In the meantime, the stunting cases in under-five children were regarded as the dependent variable.

\section{Population}

The research population involved all 24-59-month-old children in the coverage area of Puskesmas Kota Tengah.

\section{Sample}

Total sampling technique, or the sampling technique that involved the entire population, was employed to acquire the samples in the case group. A total of 34 stunted children were selected as the research sample. The controlled sample comprised 1379 normal children, and the sampling method for the control group applied the following formula:

$$
\mathrm{n}=\frac{\mathrm{N}}{1+\mathrm{N} \cdot(\mathrm{d})^{2}}
$$

$$
\begin{aligned}
& \text { Description: } \\
& \mathrm{n}=\text { number of sample } \\
& \mathrm{N}=\text { Population } \\
& \mathrm{d}=0.05
\end{aligned}
$$

The sample size retrieved in the control group consisted of 93 children; however, only 34 samples in the case group met the criteria. Therefore, the total samples that participated in the present study comprised 34 children in the case group and 34 in the control group. The total samples in the study were 68 , with a ratio of 1:1. Further, a simple random sampling technique was used to retrieve the sample in the control group [3].

The sample was determined based on the following criteria, such as (1) mothers of children are willing to have their children as the sample; (2) living in the coverage area of Puskesmas Kota Tengah; (3) healthy children; (4) not suffering from diarrhea, ARI, and malaria; (5) not experiencing congenital disorders (Atresia ani, Labiopalatoschisis, hydrocephalus).

\section{Research instrument}

The instrument was in the form of a questionnaire; the researcher designed questionnaires by referring to the books and body height measurement tools (microtoise with $0.1 \mathrm{~cm}$ accuracy).

\section{Data collection techniques}

The primary data were collected based on direct measurements by researchers accompanied by midwives. The body height data were measured by microtoise, while body weight was measured by standing weight scale. The data of age were retrieved from the children's birth certificate and/or details in the Family Card.

\section{Data analysis techniques}

\section{Univariate analysis}

The univariate analysis was conducted to acquire a general description of each variable in the study; it observed the distribution of frequency by applying the following formula [3]:

$$
P=-\times 100 \%
$$

Description:

$\mathrm{P}=$ Percentage

$\mathrm{f}=$ Frequency

$\mathrm{n}=$ Number of Population

\section{Bivariate analysis}

Bivariate analysis was carried out to investigate the interaction between the dependent variable and independent variables. The study involved independent 
variables of birth length, birth weight, provision of exclusive breastfeeding, and parity. Meanwhile, the dependent variable was the stunting cases in under-five children.

In particular, the bivariate analysis aimed to identify the effect of independent variables on the dependent variable by implementing Chi-square $\left(\chi^{2}\right)$ analysis with the following formula [4]:

$$
X^{2}=\sum \frac{\left.(f o-f h)^{2}\right)}{f h}
$$

Description:

$\mathrm{X}^{2}=$ Chi square

fo $=$ frequency obtained based on the data

$\mathrm{fh}=$ expected frequency

\section{Multivariate analysis}

The analysis intends to identify the correlation between more than one independent variable with one dependent variable. Moreover, the statistical test was the multiple regression analysis to identify which independent variable that showed the closest correlation with the dependent variable. Specifically, the study employed multiple logistic regression tests by involving Statistical Package for the Social Sciences software.

\section{Research limitation}

The study presented several limitations of research as follows. The limited size of the samples was due to the community's lack of motivation to visit the Integrated Health Service Post or Posyandu. Moreover, some of the respondents did not have the Mother and Child's Health Book; thus, the researcher adjusted the data of birth length and birth weight based on the labor register.

\section{Ethical Standards Disclosure}

This study was conducted according to the guidelines laid down in the Declaration of Helsinki, and all procedures involving research study participants were approved bythe ethics committee of Gorontalo Polytechnic of Health with the reference number of LB.01.01/KEPK/21/2020. Written and Verbal informed consent was obtained from all subjects/patients. Verbal consent was witnessed and formally recorded.

\section{Results}

Research respondents are children who are in the working area of Puskesmas Kota Tengah, Gorontalo.
The Table 1 below has shown the characteristics of the respondents.

Table 1: Distribution of respondents based on characteristics in the working area of Puskesmas Kota Tengah, Gorontalo in 2019

\begin{tabular}{lll}
\hline Variables & Total & Percentage \\
\hline Number of siblings & & \\
$>2$ people & 22 & 32.4 \\
$\quad \leq 2$ people & 46 & 67.6 \\
Age & & \\
24 s/d 36 months & 36 & 52.9 \\
$\quad 37$ s/d 59 months & 32 & 47.1 \\
Sex & 39 & 57.4 \\
$\quad$ Male & 29 & 42.6 \\
$\quad$ Female & & \\
Birth length & 28 & 41.2 \\
$\quad$ Stunted $(<48 \mathrm{~cm})$ & 40 & 58.8 \\
$\quad$ Normal $(\geq 48 \mathrm{~cm})$ & & \\
Birth weight & 26 & 38.2 \\
$\quad$ LBW (<2500 g) & 42 & 61.8 \\
$\quad$ Non-LBW $(\geq 2500 \mathrm{~g})$ & & 50.0 \\
Nutritional status & 34 & 50.0 \\
$\quad$ Stunted (Z score $<-2$ SD) & 34 & 26.5 \\
$\quad$ Normal $(Z$ score $\geq-2$ SD) & & 73.5 \\
Exclusive breastfeeding status & 18 & \\
$\quad$ Exclusive breastfeeding & 50 & \\
$\quad$ Non-exclusive breastfeeding & &
\end{tabular}

\section{Discussion}

\section{Respondents' characteristics}

\section{Children's age}

Table 1 presents that the 24-36-month-old children comprised most of the children in the coverage area of the research site (36 people, or 52.9\%), while $37-59-m o n t h-o l d$ children only comprised 32 people $(47.1 \%)$.

The term "under-five children" is divided into two age categories: under-three children (from 1 to 3 years old) and preschool-aged children (3 years old or more up to 5 years old). The under-three children group is also referred to as the passive consumer, while the preschool-aged group is referred to as the active consumer. Children under 5 years old is the age group that shows the most rapid body growth; that said, the group is also the most susceptible to experiencing malnutrition. Mothers with inadequate nutrition intake during the conception or the pregnancy stage are more prone to having a child who experiences less optimal growth. Therefore, children with malnutrition will experience less-optimal brain development; such a condition will be highly significant to hamper the children's development in preschool and school stages. Age is seen as a significant risk factor of stunting; a child's growth might go slower or faster during a particular age [5].

\section{Children's sex}

Table 1 suggests that most of the children in the coverage area of the research site are males (39 
people, or $57.4 \%$ ), while the female children are 29 people $(42.6 \%)$. Compared to male children, female children can survive in larger numbers in most countries, including Indonesia. It is a common perception that the development of a male child is influenced more by environmental pressures than that of a female child. The contrast in the nutritional status between male and female children is also impacted by the measurement standard of height/age; the standard is categorized by sex according to the anthropometric standards for assessing children's nutritional status. According to the theory and the practical condition, male children are more prone to stunted growth due to the psychological conditions. A child's psychological development involves understanding, control of expressions, and various emotions. Such a process takes into account the primary caregivers to meet their needs [6].

\section{Univariate analysis}

\section{Stunting cases in children}

Table 1 indicates that 34 (50\%) of 68 children in the coverage area of the site of research experience stunted growth. Stunting is a chronic malnutrition problem caused by insufficient nutritional intake within a long period due to the provision of food that does not meet the children's nutritional needs. Stunting occurs when the fetus is still in the womb, and only appears when the child is 2 years old. Malnutrition at an early age increases infant and child mortality; it also causes the children to get sick easily and have less optimal body posture in their adulthood stage. The children's cognitive abilities will also be reduced; in a broader sense, stunting results in long-term economic losses for Indonesia. Stunting is identified by the measurement of a child's length or height and comparison of the measurement with the established standard. If the results are below normal, the child is considered to have stunted growth [7].

\section{Birth length}

Table 1 depicts that 28 of 68 children (41.2\%) in the research area experienced stunted growth (under $48 \mathrm{~cm}$ birth length). In addition to birth weight, birth length is one of the indicators of an infant's nutritional status. A birth length between 48 and $52 \mathrm{~cm}$ is considered a normal length; thereby, infants with birth length under $48 \mathrm{~cm}$ are classified as a short infant [8]. The birth length of a newborn is obtained from data in Infant's Health Card (or KMS); the data obtained is then converted into the form of z-score index value of height/age. If the result is $\leq-2 S D$, then the newborn is categorized to have short birth length, while if the result is more than $-2 \mathrm{SD}$, the newborn is considered to have normal birth length.

\section{Birth weight}

As displayed by Table 1, 26 children from the total of 68 children $(38.2 \%$ ) have LBW. LBW is the condition in which a newborn weighs less than $2500 \mathrm{~g}$; the condition is more susceptible to risks such as death, impaired growth, slowed development, as well as the risk of stunted growth (short) if proper treatment is absent [9]. Bodyweight is the most important anthropometric measure and should be measured at every opportunity to check the health of children in all age groups. Weight loss results from the increase or decrease in all tissues in the body, including bones, muscles, fat, body fluids, and others. Up to the present, it is regarded as the best indicator to determine the state of nutrition and development of children, since bodyweight is sensitive to even the slightest change [10].

\section{Provision of exclusive breastfeeding}

As displayed in Table 1, only 18 of 68 children $(26.5 \%)$ are provided with exclusive breastfeeding. Breast milk is an infant's main food; therefore, the breastfeeding program is to be planned before delivery. Mothers are encouraged to prepare the breast milk since the pregnancy stage by taking care of ones' breasts, particularly in 2-3 months before labor. The period of breastfeeding starts as early as possible and is conducted as frequent as possible until the child is 2 years old [11].

Exclusive breastfeeding is the provision of breast milk with no additional food or drinks until the child is 6 months old. The stoppage of breastfeeding before 6 months will increase the child's risk of morbidity and mortality [12]. The notion is strengthened by the $\mathrm{WHO}$, which recommends that breastfeeding is carried out until the child is 6 months old.

\section{Number of siblings}

As displayed from Table 1, 22 (32.4\%) of 68 respondents are having more than two siblings.

On top of that, too many children in a family require immense attention from parents; the condition can also create a less-conducive atmosphere at home. A noisy atmosphere at home will disturb the peace of mind; this might directly impact the appetite of other family members that might notice such less conducive atmosphere. In addition, a low-income family with the number of family members exceeding the family's capacity to support them is considered a "susceptible" family due to the lack of assurance regarding the equal distribution and adequacy of food in the family. It will be difficult for a susceptible family to fulfill its members' nutritional needs; thus, the family is more prone to diseases. 


\section{Bivariate analysis}

Correlation between birth length and stunting

cases

The following Table 2 indicates the correlation between birth length and stunting cases in the working area of Puskesmas Kota Tengah, Gorontalo.

Table 2: Correlation between birth length and stunting cases in the working area of Puskesmas Kota Tengah, Gorontalo in 2019

\begin{tabular}{|c|c|c|c|c|c|c|c|}
\hline \multirow[t]{3}{*}{ Birth length } & \multicolumn{4}{|c|}{ Stunting cases } & \multirow{2}{*}{\multicolumn{2}{|c|}{ Total }} & \multirow{3}{*}{$\begin{array}{l}\chi^{2} \text { count } \\
\rho \text { value } \\
\text { OR }\end{array}$} \\
\hline & \multicolumn{2}{|c|}{ Stunting } & \multicolumn{2}{|c|}{ Normal } & & & \\
\hline & $\mathrm{n}$ & $\%$ & $\mathrm{n}$ & $\%$ & $\mathrm{n}$ & $\%$ & \\
\hline Short & 21 & 75.0 & 7 & 25.0 & 28 & 100.0 & 11.900 \\
\hline Normal & 13 & 32.5 & 27 & 67.5 & 40 & 100.0 & 0.001 \\
\hline Total & 34 & 50.0 & 34 & 50.0 & 68 & 100.0 & 6.231 \\
\hline
\end{tabular}

Table 2 highlights that 21 children with less than $48 \mathrm{~cm}$ birth length (75\%) experience stunted growth, while 27 children with normal birth length $(67.5 \%)$ have normal nutritional status. From the Chi-squared test, it is obtained that the $\chi^{2}$ count $=11.900$ and $\rho=0.001$; thus, $\chi^{2}$ count $(11.900)>\chi^{2}$ table (3.841), and $\rho$ value $(0.001)$ $<\alpha(0.05)$. From the analysis result, it is interpreted that there is a significant correlation between birth length and stunting cases in 24-59-month-old children in the site area. In addition, the statistical test yields the odd ratio value of 6.231 that is to say, children with birth length less than $48 \mathrm{~cm}$ are 6.231 times more at risk of stunting compared to children with normal birth length.

In cases where children with normal birth length experience stunting, the findings might be correlated with the mothers' occupation, in which 12 of 13 mothers have no occupation; hence, the condition leads to low economic status. Low economic status is impactful on the quality and quantity of food consumption in a family. The foods presented on the table, particularly foods that encourage the children's growth, are usually less varied and less in quantity.

Short birth height cases indicate the mother's lack of nutritional supply during pregnancy; simply put, the lack of nutrition intake leads to less-optimal growth of the fetus. Improved intake of nutritious food is of paramount significance in encouraging the growth of children with short birth height to achieve normal height as the children grow older.

In the same tune, birth height less than $48 \mathrm{~cm}$ is at risk of stunting [13]. The risk of faltering growth is larger for the children that have experienced falter previously in the pregnancy and prematurity stages. In other words, newborns with far lower body lengths than average have experienced growth retardation since in the womb.

It is also found out that $205(30.1 \%)$ of 681 children with short birth length experienced stunted growth ( $p=0.000<0.05$ ), thus the null hypothesis was rejected, that is, that there was a relationship between birth length and stunting cases in children aged 12-59 months in Lampung Province [14]. Rahmadi's study also yielded an odds ratio of 1.56 , which means that newborns with short birth length are 1.56 times riskier of becoming stunted compared to newborns with normal growth [14].

Echoing the previous findings, another also emphasizes the correlation between birth length and the incidence of stunting; they found that the under-two children with short birth length had a 6.29 times greater risk of becoming stunted than the children with normal birth length [15].

A child's birth length is an indicator of the linear growth of the child during one's period in the womb. Low linear growth generally suggests the inadequate nutritional status due to the lack of energy and protein intake in the past; the condition begins with the slow down or retardation of fetal growth [16].

\section{Correlation between birth weight and stunting cases}

The correlation between birth weight and stunting cases in the working area of Puskesmas Kota Tengah, Gorontalo, is displayed in the Table 3 below.

Table 3: Correlation between birth weight and stunting cases in the working area of Puskesmas Kota Tengah, Gorontalo in 2019

\begin{tabular}{|c|c|c|c|c|c|c|c|}
\hline \multirow[t]{3}{*}{ Birth weight } & \multicolumn{4}{|c|}{ Stunting cases } & \multirow{2}{*}{\multicolumn{2}{|c|}{ Total }} & \multirow{3}{*}{$\begin{array}{l}X^{2} \text { count } \\
\rho \text { value } \\
\text { OR }\end{array}$} \\
\hline & \multicolumn{2}{|c|}{ Stunting } & \multicolumn{2}{|c|}{ Normal } & & & \\
\hline & $\mathrm{n}$ & $\%$ & $\mathrm{n}$ & $\%$ & $\mathrm{n}$ & $\%$ & \\
\hline LBW & 19 & 73.1 & 7 & 26.9 & 26 & 100.0 & 8.967 \\
\hline Non LWB & 15 & 35.7 & 27 & 64.3 & 42 & 100.0 & 0.003 \\
\hline Total & 34 & 50.0 & 34 & 50.0 & 68 & 100.0 & 0.205 \\
\hline
\end{tabular}

Table 3 suggests that 19 children (73.1\%) with LBW (<2500 g) experience stunted growth; the number is higher than children with normal birth weight that experienced stunted growth (15 children, or $35.7 \%$ ). In the latter case, this might be due to the factor mother's education level, as 13 of 15 mothers have low educational background. Such condition is the factor of mothers' lack of knowledge of nutrition; thus, it will lead to the improper provision of nutrition that is not suitable for infants, such as the lack of exclusive breastfeeding in the first 6 months. Whereas, as recommended by the $\mathrm{WHO}$, breast milk is the best food for newborns until they are 2 years old.

From the Chi-squared test, it is acquired that the $\chi^{2}$ count $=8.967$ and $\rho$ value $=0.003$; thus, $\chi^{2}$ count $(8.967)>\chi^{2}$ table $(3.841)$, and $\rho$ value $(0.003)<\alpha$ (0.05). As the $\mathrm{Ha}$ is accepted, therefore, it signifies that there is a significant correlation between birth weight and stunting cases in 24-59 months old children in the research area. On top of that, the statistical test yields the odd ratio value of 0.205 , indicating that children with LBW are 0.205 times more at risk to stunting compared to children with normal birth length.

Newborns with LBW can experience digestive tract disorders because the infants' digestive tract is not functioning properly. Therefore, they are unable to absorb the food optimally; such conditions will lead to 
electrolyte disorders. Infants with LBW also experience breastfeeding problems because of their small body size, weakness, and small stomach, and inability to feed on breast milk optimally. As a result, the baby's growth will be hampered. If such a situation continues with inappropriate feeding (e.g., lack of exclusive breastfeeding), the child will often experience infections and grow to be stunted.

This notion is supported by Dewi's research whose Chi-squared test showing that there is a relationship between birth weight and stunting ( $p=0.042)$; the study yielded OR value of 0.157 , which means that under-two children who had a history of LBW are 0.157 times more likely to experience stunting than those without LBW [17].

In line with that, a research discovered that 16 out of 22 under-five children experienced stunted growth [18]. The study's Chi-squared test obtained $p=0.000$ (or <0.05); hence, it suggests that there is a significant relationship between LBW and the stunting cases in under-five children at Puskesmas Lima Puluh in Pekanbaru.

Another research also figured out that children with a history of LBW had a 5.87 times higher chance of experiencing stunting [19]. This is due to the fact that birth weight is strongly associated with fetal mortality, neonatal and post-neonatal mortality, infant and child morbidity, and child's long-term growth and development. In a broader sense, the impact of LBW in children will continue for generations. Children with LBW will have less anthropometric measures in their development. Such conditions can occur because newborns with LBW have experienced intrauterine growth retardation since in the womb [5]. The state will continue until the next age after birth; the children are at risk of experiencing slower growth and development than children with normal weight. In some cases, they often fail to catch up with the level they should have attained after birth.

The anti-immune compounds in children with LBW are less optimal; hence, the children are more prone to disease, particularly infectious diseases. Such diseases will in turn decrease the children's appetite. It will then decrease the amount of food intake that enters the body and lead to malnutrition [20].

Further, a child born with LBW that grows stunted will experience health problems and less productivity. At school stage, if there is no improvement in adequate nutrition and good health services, the health problems will continue to the next stage and the child will grow to a short adolescent.

\section{The Correlation between Exclusive Breastfeeding and Stunting Cases}

The following Table 4 indicates the correlation between exclusive breastfeeding and stunting cases in the working area of Puskesmas Kota Tengah, Gorontalo.

Table 4: Correlation between exclusive breastfeeding and stunting cases in the working area of Puskesmas Kota Tengah, Gorontalo in 2019

\begin{tabular}{|c|c|c|c|c|c|c|c|}
\hline \multirow[t]{3}{*}{ Provision of exclusive breastfeed } & \multicolumn{4}{|c|}{ Stunting cases } & \multirow{2}{*}{\multicolumn{2}{|c|}{ Total }} & \multirow{3}{*}{$\begin{array}{l}x^{2} \text { count } \\
\rho \text { value } \\
\text { OR }\end{array}$} \\
\hline & \multicolumn{2}{|c|}{ Stunting } & \multicolumn{2}{|c|}{ Normal } & & & \\
\hline & $\mathrm{n}$ & $\%$ & $\mathrm{n}$ & $\%$ & $\mathrm{n}$ & $\%$ & \\
\hline Exclusive breastfeeding & 2 & 11.1 & 16 & 88.9 & 18 & 100.0 & 14.809 \\
\hline Non-exclusive breastfeeding & 32 & 64.0 & 18 & 36.0 & 50 & 100.0 & 0.000 \\
\hline Total & 34 & 50.0 & 34 & 50.0 & 68 & 100.0 & 14.2 \\
\hline
\end{tabular}

Table 4 shows that only low percentage of children provided with exclusive breastfeeding grow stunted (two children, or $11.1 \%$ ). The percentage is significantly lower than children without exclusive breastfeeding who experienced stunted growth (32 children, or $64.0 \%$ ).

From the Chi-squared test, it is acquired that the $\chi^{2}$ count $=14.809$ and $\rho$ value $=0.000$; thus, $\chi^{2}$ count $(14,809)>\chi^{2}$ table $(3,841)$, and $\rho$ value $(0,000)$ $<\alpha(0.05)$. Accordingly, it is interpreted that there is a significant correlation between provision of exclusive breastfeeding and stunting cases in 24-59-monthold children in the research area. The statistical test yields the odd ratio value of 14.2, meaning that children without exclusive breastfeeding are 14.2 times riskier to stunting compared to children provided with exclusive breastfeeding.

In cases where children who are exclusively breastfed but still experience stunting, this might be due to the mothers' occupation. Working mothers have fewer opportunities to care for their children; such a condition will affect the children's nutritional status. This is also in accordance with a study that shows about $80 \%$ of working mothers have children with abnormal growth. The high percentage blames the mothers' limited time to care for their children.

The availability of formula milk in the market is to blame for the mothers' lack of eagerness to increase their breast milk production. Despite that formula milk is able to fulfill the children's nutritional needs, it does not contain antibodies as complete as breast milk. For this reason, children that only consume formula milk are more prone to disease [21].

The lack of breastfeeding is considered a threat to child development. In a broader sense, lack of breastfeeding can hamper the development of the quality of human resources in general. Proper breastfeeding by the mother will help maintain the child's nutritional balance to promote optimal growth. That said, breast milk is highly crucial as a means of nutrition fulfillment during the children's growth period. Therefore, mothers are highly encouraged to provide exclusive breastfeeding to their children until 6 months old and continue to provide breast milk until the baby is 2 years old to achieve an optimal nutritional status [22].

A research explained that the stunting cases in under-five children both in rural and urban 
areas are influenced by the variable of exclusive breastfeeding [23]. The low level of exclusive breastfeeding is one of the determinant factors for stunting in children. Such a condition is caused by past events and will influence the children's future. On the other hand, regular breastfeeding by mothers will help maintain the children's nutritional balance.

This is in compliance with Indrawati's research regarding the relationship between exclusive breastfeeding and stunting cases in children aged 2-3 years in Karangjerek village, Wonosari, Gunung Kidul [24]. The study yielded $p=0.000$ (or below 0.05 ), therefore, it is interpreted that the provision of exclusive breastfeeding is highly correlated with stunting cases in the research site. Breast milk is considered a source of nutrition that promotes the children's growth and development. Children who do not get enough breast milk will have poor nutritional intake and experience malnutrition, one of determinants of stunting. Exclusive breastfeeding is proven to support the children's growth; particularly, it promotes the children's optimal height growth because the calcium from breast milk is absorbed more efficiently than formula milk or other substitutes.

Echoing the notion, a study yielded Chi-square test results showing that $p=0.003$ (or below 0.05 ) [25]. Hence, it is implied that there is a relationship between a history of exclusive breastfeeding and the stunting cases in children aged 12-36 months in the working area of Puskesmas Luwuk, South Luwuk District, Banggai Regency, Central Sulawesi.

A study found the same results, that is, significant relationship between exclusive breastfeeding and stunting cases [6]. Exclusive breastfeeding is considered essential for children's growth to reduce and prevent infection. The findings that indicated mothers' attitude toward exclusive breastfeeding might be caused by the overall low level of education. Mothers with low level of education are unaware of the importance of exclusive breastfeeding to the children.

\section{Cases}

\section{Correlation between Parity and Stunting}

The Table 5 below is shown the correlation between parity and stunting cases in the working area of Puskesmas Kota Tengah, Gorontalo.

Table 5: Correlation of parity and stunting cases in the working area of Puskesmas Kota Tengah, Gorontalo in 2019

\begin{tabular}{|c|c|c|c|c|c|c|c|}
\hline \multirow[t]{3}{*}{ Parity } & \multicolumn{4}{|c|}{ Stunting cases } & \multirow{2}{*}{\multicolumn{2}{|c|}{ Total }} & \multirow{3}{*}{$\begin{array}{l}x^{2} \text { count } \\
\rho \text { value } \\
\text { OR }\end{array}$} \\
\hline & \multicolumn{2}{|c|}{ Stunting } & \multicolumn{2}{|c|}{ Normal } & & & \\
\hline & $\mathrm{n}$ & $\%$ & $\mathrm{n}$ & $\%$ & $\mathrm{n}$ & $\%$ & \\
\hline High & 13 & 59.1 & 9 & 40.9 & 22 & 100.0 & 1.075 \\
\hline Low & 21 & 45.7 & 25 & 54.3 & 46 & 100.0 & 0.300 \\
\hline Total & 34 & 50.0 & 34 & 50.0 & 68 & 100.0 & 1.72 \\
\hline
\end{tabular}

Table 5 shows that children who were born to mothers with low parity are more likely to experience stunting (21 people, or $45.7 \%$ ) compared to children born to mothers with high parity (13 people, or $59.1 \%$ ).
Cases where stunted children were born to mothers with low parity might be due to the factor of mothers' education. As the study discovered, 19 out of 21 mothers with stunted children have low level of education. Consequently, mothers' lack of knowledge on the children's nutrition status will more likely lead to lack of intake of essential nutrients that are needed for the children's growth.

As based on the Chi-squared test result, it signifies that the $\chi^{2}$ count $=1.075$ and $\rho$ value $=0.3$; thus, $\chi^{2}$ count $(1.075)>\chi^{2}$ table (3.841), and $\rho$ value $(0.3)<\alpha(0.05)$. As the $\mathrm{H}_{a}$ is rejected and the $\mathrm{H}_{0}$ is accepted, it is indicated that there is no correlation between parity and stunting cases in 24-59-month-old children in the research area.

Parity is one of the maternal factors of LBW, in which parity is very influential on the conception result [5]. High level of parity is riskier than low parity. The notion is supported by the fact that parity leads to many complications in pregnancy due to too much giving birth. Therefore, this study concludes that parity has no effect or no correlation with the stunting cases.

The present work is different from the study conducted by Palino, which discovered that stunted children tend to have mothers with high parity, while non-stunted children tend to have mothers with low parity [26]. In other words, mothers with high parity tend to have children who will grow stunted. Such condition takes place because families with many children, especially those with poor economic status, will not be able to provide adequate attention and food to all of the children. Children who are in rapid growth period, particularly those in the age of 1-2 years, require immense attention and stimulation for brain development in addition to requiring adequate amount of nutrients for their physical growth. Children born in later delivery tend to experience growth and development disorders, since parents' burden will get bigger as the number of children increases.

\section{Multivariate analysis}

As based on Table 6, the multiple logistic regression multivariate analysis suggests that all variables have $p>0.05$ (Birth Length: 0.085, Birth Weight: 0.117, and Exclusive Breastfeeding: 0.055). The variable with the largest $p$-value is birth weight. Hence, in the next modeling stage, the birth weight variable is excluded. Afterward, further analyses were conducted up to the third modeling analysis. The results are as follows:

Following Table 7, it is identified that the only variable remaining is exclusive breastfeeding, with $p=$ 0.006 (or below 0.05). Therefore, the present model is the final model of multivariate analysis on the determinant factor of stunting cases in the research area. 
Table 6: Multiple logistic regression multivariate analysis on the correlation of birth length, birth weight, and provision of exclusive breastfeed with stunting cases in the working area of Puskesmas Kota Tengah, Gorontalo in 2019

\begin{tabular}{|c|c|c|c|c|c|c|c|c|}
\hline \multirow[t]{2}{*}{ Variable } & \multirow[t]{2}{*}{ B } & \multirow[t]{2}{*}{ S.E. } & \multirow[t]{2}{*}{ Wald } & \multirow[t]{2}{*}{$\mathrm{df}$} & \multirow[t]{2}{*}{ Sig. } & \multirow[t]{2}{*}{$\operatorname{Exp}(\mathrm{B})$} & \multicolumn{2}{|c|}{$95 \%$ C.I for $\operatorname{Exp}(B)$} \\
\hline & & & & & & & Lower & Upper \\
\hline Birth length & -1.076 & 0.626 & 2.958 & 1 & 0.085 & 0.341 & 0.100 & 1.162 \\
\hline Birth weight & 0.960 & 0.612 & 2.460 & 1 & 0.117 & 2.612 & 0.787 & 8.668 \\
\hline $\begin{array}{l}\text { Provision of } \\
\text { exclusive } \\
\text { breastfeed }\end{array}$ & -1.719 & 0.897 & 3.671 & 1 & 0.055 & 0.179 & 0.031 & 1.040 \\
\hline Constant & 0.642 & 0.513 & 1.561 & 1 & 0.211 & 1.899 & & \\
\hline
\end{tabular}

The results of multivariate analysis show that exclusive breastfeeding is the most dominant variable that affects the stunting cases. The analysis of the variable yielded an odds ratio (OR) of 0.103 , signifying that mothers who did not provide exclusive breastfeeding had a risk of 0.103 times to have their children to grow stunted compared to the children who were given exclusive breastfeeding.

Table 7: Results of multiple logistic regression multivariate analysis on the determinant factors of stunting cases in 24-59 months old children in the working area of Puskesmas Kota Tengah, Gorontalo in 2019

\begin{tabular}{|c|c|c|c|c|c|c|c|c|}
\hline \multirow[t]{2}{*}{ Variable } & \multirow[t]{2}{*}{ B } & \multirow[t]{2}{*}{ S.E. } & \multirow[t]{2}{*}{ Wald } & \multirow[t]{2}{*}{ df } & \multirow[t]{2}{*}{ Sig. } & \multirow[t]{2}{*}{$\operatorname{Exp}(B)$} & \multicolumn{2}{|c|}{$95 \%$ C.I for $\operatorname{Exp}(B)$} \\
\hline & & & & & & & Lower & Upper \\
\hline $\begin{array}{l}\text { Provision of } \\
\text { exclusive } \\
\text { breastfeed }\end{array}$ & -2.274 & 0.835 & 7.420 & 1 & 0.006 & 0.103 & 0.020 & 0.528 \\
\hline Constant & 0.118 & 0.396 & 0.089 & 1 & 0.766 & 1.125 & & \\
\hline
\end{tabular}

From the results of the bivariate analysis that employed Chi-squared test, it is indicated that the variables of birth length, birth weight and exclusive breastfeeding are determinants factors of stunting, while parity is not. The analysis then proceeds to the multivariate analysis. It was found that exclusive breastfeeding is the most significant determinant on stunting cases.

The lack of dominant impact of birth length and birth weight variables is assumed to be caused by good parenting methods. Simply put, children that acquire good nutrition will generally experience linear changes in their body size and gain more weight.

The children's linear size growth will be improved if their nutritional needs are fulfilled; thus, the children will be able to catch up gradually with the normal growth in terms of height and weight. As shown by the statistics, birth length and birth weight have high enough significance value. Therefore, both variables must be excluded from the model.

Stunting is an indicator of nutritional status that describes any existing chronic nutritional problems due to the influence of long exposure. This serves as the reason why exclusive breastfeeding is a determinant factor of stunting. Breast milk is considered the best food for infants due to its complete nutrient contents in an appropriate portion. The risk of becoming stunted was 3.7 times higher in infants who were not given exclusive breastfeeding compared to those who were given exclusive breastfeeding [27]. In the previous research, it was also shown that children who did not get colostrum are riskier to grow stunted. This might be on account of colostrum that exerts a protective effect in newborns. That said, infants who do not receive colostrum might have a higher incidence, duration and severity of illnesses (e.g., diarrhea) that will contribute to malnutrition.

As the findings suggested, the study recommends the implementation efforts to prevent stunting. The conduct can start in women's adolescence age, for example, by improving their nutritional status, providing additional food, and consuming blood supplement tablets during menstruation to prevent anemia. In addition, prevention of stunting from family is of significance, since the family is the first environment that interacts with the baby. The first 2 years of a child's life, known as the first 1000 days of life, are very critical period for one's growth and development. During this period, the family, especially parents, must ensure that the baby is getting adequate and appropriate nutrition to prevent malnutrition and other factors leading to stunting. Exclusive breastfeeding is the cheapest and easiest way to ensure the fulfillment of a child's nutritional needs. The benefits of exclusive breastfeeding are proven to aid children to get adequate nutritional intake to minimize the risk of stunting. Therefore, the mothers' preparation of exclusive breastfeeding must start during pregnancy by counseling on exclusive breastfeeding during Antenatal Care. Moreover, the preparation should continue in the Early Initiation of Breastfeeding (IMD) during Intranatal Care until the provision of exclusive breastfeeding until months.

\section{Conclusions}

As based on the analysis results on the determinant factors of stunting cases in the research area, the study concludes that birth length, birth weight, provision of exclusive breastfeeding, number of siblings are correlated with stunting cases in 24-59-month-old children in the working area of Puskesmas Kota Tengah, Gorontalo. On the top of all, exclusive breastfeeding is the significant determinant factor of stunting cases in 24-59-month-old children in the research site.

\section{Recommendation}

It is hoped that the Puskesmas and Midwives can improve better nutritional status of the children by providing counseling about nutrition, especially nutrition in the first 1000 days of life to prevent stunted children without to rule out risk factors for stunting in order to produce future generations with quality. 


\section{Acknowledgments}

The authors would like to express their gratitude to all the participants and community health center in Kota Tengah for their contribution to this research.

\section{References}

1. Sandjojo EP. Buku Saku Desa Dalam Penanganan Stunting [Village pocket book in handling stunting]. Jakarta: Kementerian Desa Pembangunan Daerah Tertinggal dan Transmigrasi; 2017.

2. Millennium Challenge Corporation. Gambaran Umum Proyek Kesehatan dan Gizi Berbasis Masyarakat Untuk Mengurangi Stunting [Overview of a Community-Based Health and Nutrition Project to Reduce Stunting]. Washington, DC: Millennium Challenge Corporation; 2016. Available from: https://www.mcc. gov/resources/story/section-ind-star-report-health-project [Last accessed on 2019 Sep 21].

3. Ariani A. Aplikasi Metodologi Penelitian Kebidanan dan Kesehatan Reproduksi [Application of Research Methodology in Obstetrics and Reproductive Health]. Yogyakarta: Nuha Medika; 2014.

4. Notoatmodjo S. Metodologi Penelitian Kesehatan [Health Research Methodology]. Jakarta: Rineka Cipta; 2012.

5. Proverawati A, Wati EK. IImu Gizi Untuk Keperawatan dan Gizi Kesehatan [Nutritional Science for Nursing and Health Nutrition]. Yogyakarta: Nuha Medika; 2011.

6. Mugiyanti S, Mulyadi A, Anam AK, Najah ZL. Faktor penyebab anak stunting Usia 25-60 bulan di Kecamatan Sukorejo Kota Blitar [Factors causing stunting children aged $25-60$ months in Sukorejo district, Blitar City]. J Polytec of Malang Healt Minis. 2018;5(3):268-78.

7. Millennium Challenge Corporation. Stunting dan Masa Depan Indonesia [Stunting and Indonesia's future]. Washington, DC: Millennium Challenge Corporation; 2015. Available from: https:// www.mcc.gov/resources/pub-full/star-report-indonesia [Last accessed 2019 Oct 05].

8. Trihono $\mathrm{T}$, Atmarita $\mathrm{A}$, Tjandrarini $\mathrm{DH}$, Irawati $\mathrm{A}$, Utami $\mathrm{NH}$ Tejayanti T, et al. Stunting di Indonesia, Masalah dan Solusinya [Stunting in Indonesia, Problems and Solutions]. Jakarta: Lembaga Penerbit Balitbangkes; 2015.

9. InfoDATIN. Situasi Balita Pendek [Short Toddler Situation] Jakarta: Pusat Data dan Informasi Kementerian Kesehatan RI; 2016.

10. Soetjiningsih S. Tumbuh Kembang Anak [Child Development]. Jakarta: EGC; 2012.

11. Hayati W. Buku Saku Gizi Bayi [Baby Nutrition Pocket Book]. Jakarta: EGC; 2009.

12. Ranuh IG. Beberapa Catatan Kesehatan Anak [Some Children's Health Records]. Jakarta: Sagung Seto; 2013.

13. Khoirun N, Nadhiroh SR. Faktor yang berhubungan dengan kejadian stunting pada balita [Factors related to the incidence of stunting in children under five]. Indo Nutri Med. 2015;10(1):13-9.

14. Rahmadi A. Hubungan berat badan dan panjang badan lahir dengan kejadian stunting anak usia 12-59 bulan di provinsi Lampung [The relationship between body weight and birth length and the incidence of stunting in children aged 12-59 months in Lampung province]. J Nutri of Tanjung Karang Polytec. 2016;7(2):209-18.
15. Wellina WF, Kartasurya MI, Rahfilludin MZ. Faktor risiko stunting pada anak umur 12-24 bulan [Risk factors for stunting in children aged 12-24 months]. J Medic Fac of Undip. 2016;5(1):55-61.

16. Swathma D, Lestari H, Ardiansyah RT. Analisis faktor risiko BBLR, panjang badan bayi saat lahir dan riwayat imunisasi dasar terhadap kejadian stunting pada balita usia 12-36 bulan di wilayah kerja Puskesmas Kandai Kota Kendari [Analysis of LBW risk factors, baby body length at birth and history of basic immunization against the incidence of stunting in children aged 12-36 months in the working area of the Kandai Health center, Kendari city]. J Pub Healt Fac of UHO. 2016;1(1):1-10. https:// doi.org/10.32382/mgp.v25i1.55

17. Dewi NT. Hubungan berat badan lahir rendah dan penyakit infeksi dengan kejadian stunting pada baduta di Desa Maron Kidul Kecamatan Maron Kabupaten Probolinggo [Relationship between low birth weight and infectious diseases with the incidence of stunting in baduta in Maron Kidul village, Maron district, Probolinggo regency]. J Pub Healt Offic of Surabaya. 2018;2(4):373-81. https://doi.org/10.20473/amnt. v2i4.2018.373-381

18. Fitri L. Hubungan BBLR dan ASI eksklusif dengan kejadian stunting di Puskesmas Lima Puluh Pekanbaru [The relationship between low birth weight and exclusive breastfeeding with the incidence of stunting at Puskesmas Lima Puluh Pekanbaru]. J Midwi Aca Helvetia of Pekanbary. 2018;3(1):131-7. https://doi. org/10.22216/jen.v3i1.1767

19. Rahayu A, Yulidasari F, Putri AO, Rahman F. Riwayat berat badan lahir dengan kejadian stunting pada anak usia bawah dua tahun [History of birth weight and incidence of stunting in children under two years of age]. J Medic Fac of ULM. 2015;10(2):67-73. https://doi.org/10.21109/kesmas.v10i2.882

20. Imelda I, Rahman N, Nur R. Faktor risiko kejadian stunting pada anak umur 2-5 tahun di wilayah kerja Puskesmas Biromaru Kabupaten Sigi [Risk factors for the incidence of stunting in children aged 2-5 years in the work area of the Biromaru Health center, Sigi regency]. J Pub Healt of UNTAD. 2016;2(1):39-43. https://doi.org/10.22487/ghidza.v2i1.6

21. Pangkong $M$, Rattu AJ, Malonda NS. Hubungan antara pemberian asi eksklusif dengan kejadian stunting pada anak usia 12-36 bulan di wilayah kerja Puskesmas Sonder [The relationship between exclusive breastfeeding and the incidence of stunting in children aged 12-36 months in the working area of the Sonder Health center]. J Pub Healt of Unsrat. 2016;1(1):1-10.

22. Azriful A, Bujawati E, Habibi H, Aeni S, Yusdarif Y. Determinan kejadian stunting pada balita usia 24-59 bulan di Kelurahan Rangas Kecamatan Banggae Kabupaten Majene [The determinant of the incidence of stunting in children aged 24-59 months in Rangas village, Banggae district, Majene regency]. J Pub Healt of UIN-Alauddin. 2018;10(2):192-203.

23. Aridiyah FO, Rohmawati N, Ririanty M. Faktor-faktor yang mempengaruhi kejadian stunting pada anak balita di wilayah pedesaan dan perkotaan [Factors that influence the incidence of stunting in children under five in rural and urban areas]. J Pub Healt of UNEJ. 2015;3(1):163-70.

24. Indrawati S, Warsiti W. Hubungan Pemberian Asi Eksklusif Dengan Kejadian Stunting Pada Anak Usia 2-3 Tahun di Desa Karangjerek Wonosari Gunungkidul [The Relationship between Exclusive Breastfeeding and the Incidence of Stunting in Children Aged 2-3 Years in Karangjerek Wonosari village, Gunungkidul]. UNISA Digital Library-Repository; 2019. Available from: http://www.digilib.unisayogya.ac.id/2480 [Last accessed on 2017 Nov 16].

25. Johan $\mathrm{P}$, Kawengian $\mathrm{S}$, Rombot DV. Hubungan antara riwayat pemberian ASI eksklusif dengan kejadian stunting pada anak usia 12-36 bulan di wilayah Kerja Puskesmas Luwuk Kecamatan Luwuk Selatan Kabupaten Banggai Sulawesi Tengah [The relationship between a history of exclusive breastfeeding and the incidence of stunting in children aged 12-36 months in the 
Luwuk Health center, Luwuk Selatan district, Banggai regency, Central Sulawesi]. J Pub Healt of of Unsrat. 2015;1(1):1-8.

26. Palino IL, Majid R, Ainurafiq A. Determinan kejadian stunting pada balita usia 12-59 bulan di wilayah kerja Puskesmas Puuwatu Kota Kendari tahun 2016 [Determinants of the incidence of stunting in toddlers aged 12-59 months in the Puuwatu Public
Health Center Kendari city 2016]. JIM Pub Healt. 2016;2(4):1-12.

27. Nadiya N, Briawan D, Martianto D. Faktor risiko stunting pada anak usia 0-23 bulan di Provinsi Bali, Jawa Barat, dan Nusa Tenggara Timur [Risk factors for stunting in children aged 0-23 months in the Provinces of Bali, West Java and East Nusa Tenggara]. J Nut Food. 2014;9(2):125-32. 